\title{
Pragmatic Features of the Speech Act of Compliment in a Turkish TV Drama
}

\author{
Mohammad Hossein Keshavarz* \\ Girne American University \\ North Cyprus \\ E-mail: keshavarz22@gmail.com
}

\section{Yasemin Çetereisi}

Near East University

North Cyprus

Email: yaseminadil@hotmail.co.uk

\section{Gulay Asit}

Girne American University

North Cyprus

Email: gulayasit@gmail.com

\section{*(Corresponding Author)}

DOI: https://doi.org/10.1836/jopr.v2i1.1-25

\begin{tabular}{ll}
\hline Submission & ABSTRACT \\
Track: & Research on the speech act of compliment is abundant; however, \\
Received: & studies on the characteristics of compliments in Turkish, in general, \\
01-01-2020 & and in Turkish TV dramas, in particular, are scarce. Therefore, to \\
Final Revision: & fill this research gap, the present study set out to investigate the use \\
02-04-2020 & of compliments in a popular Turkish soap opera. To achieve the \\
Available online: & purposes of this research, thirty-two episodes of a TV drama called \\
06-04-2020 & Sahra were selected at random to be viewed and analysed while \\
Corresponding & focusing on the topics, functions, and characteristics of compliments \\
Author: & with reference to the role of gender. Four main topics and functions, \\
Mohammad &
\end{tabular}


Hossein Keshavarz

keshavarz22@gmail.com and two major characteristics of Turkish compliments emerged from the analysis of the data. Similarities and differences were also found in the use of compliments in Turkish and other languages. The findings may have implications for research on speech acts, in general, and complimenting behaviour in TV dramas, in particular.

Keywords: Turkish compliments; TV drama; elaboration; exaggeration; gender

\section{INTRODUCTION}

Compliment is a universal speech act that is frequently used in daily interactions of people in different cultures. As the expression of admiration or approval, compliments serve a variety of functions including admiring the addressee's beauty, appearance, performance, and personality traits. They can also be used simply to open a conversation and establish communication. For example, it is quite common to compliment on a stranger's child in a park as "What a cute baby!". This could be considered a phatic communion whose purpose is to indicate the willingness of the speaker to establish communication with the addressee, and not necessarily expressing a fact. Manes (1983) views compliments from a cultural perspective and compares it to a window "through which a society as a whole or an individual in particular can view what is valued by a relevant culture" (p.97). In the same vein, Keshavarz (2015) argues that "compliments are universal in the sense that each and every culture has some ways of admiring and praising the positive attributes of its members, but the nature and frequency of compliments vary from culture to culture" (p. 40).

Similarly, Wolfson (1983) asserts that "compliments differ cross-culturally not only in the way they are structured but also in their distribution, their frequency of occurrence, and the function they serve" (p.87). Holmes (1986) also highlights the values of doing research in this area by stating that "research in complimenting behaviour will clearly prove a fruitful and fascinating area of pragmatics and sociolinguistics" (p. 505).

Interest in the complimenting speech act goes back to the 80 s when some pioneering studies were conducted in this area (e.g., Holmes, 1986, 1988; Manes \& Wolfson, 1981; Manes, 1983; Wolfson, 1983). Since then, compliments and compliment responses have received a great deal of attention from researchers in different parts of the globe. In fact, recent publications show that interest in this speech act has not faded away yet (e.g., Al-Mansoob, Patil, \& Alrefaee, 
2019; Boroujeni, Domakani, \& Sheykhi, 2016; Eslami, Jabbari, \& Kuo 2015; Farenkia, 2013; Furko \& Dudas, 2012; Monjezi, 2014; Morales, 2012; Negargar, 2015; Salgado \& Witten, 2019; Saifi \& Sultani, 2017; Salgado \& Witten, 2019; Sawadogo, 2018; Shokouhi \& Rezaei, 2015).

The topic of compliments may vary from culture to culture. For example, "in American culture it is quite normal to directly compliment on the wife of one's acquaintance, e.g., Your wife is very beautiful!, while in the Middle-Eastern culture, in most cases, such a compliment may create problems for both the complimenter and the complimentee" (Keshavarz, 2015, pp. 4041). Baek (1998) also states that topics of compliments are related to cultural norms and values and functions of compliments serve as the reflection of culture. Topics of compliments have traditionally been classified into three main categories, as follows:

1. Appearance/possessions: You look smart today.

2. Performances/skills/abilities. Your presentation was impressive.

3. Personality traits: I wish I were as talented as you are.

From the point of view of politeness, compliment is normally considered as a facesaving speech act since by paying a compliment the speaker emphasizes the addressee's positive face, given that it is a natural desire to be liked and admired by others (cf. Brown \& Levinson, 1987). Compliments can also be flattery when the speaker is not sincere about the compliment $\mathrm{s} / \mathrm{he}$ gives. That is, the speaker intends to achieve something, such as a favour, through exaggerating on the object of compliment or unduly praising a quality of the addressee. Exaggeration was, indeed, one of the themes that emerged from the data of the current study, as will be discussed in the following sections.

With regard to the structure of compliments, a large-scale pioneering study was conducted by Manes and Wolfson (1981) with a corpus of 686 compliments in American English. The population of their study consisted of speakers representing different dialects of American English. Their study yielded nine syntactic patterns that are highly structured and formulaic, as shown in Table 1.

Table 1. Compliment Syntactic Patterns

No. Syntactic Patterns $\quad$ Example Sentences




\begin{tabular}{lll}
\hline 1 & NP is/looks (really) ADJ & Your blouse is/looks (really). \\
2 & I (really) like/love NP) & I (really) like/love your car. \\
3 & PRO is (really) (a) ADJ NP & That's a (really) nice painting. \\
4 & You V a (really) ADJ NP & You did a (really) good job. \\
5 & You (really) V (NP) ADV & You really handled that situation well. \\
6 & You have (a) ADJ NP! & You have beautiful eyes! \\
7 & What (a) ADJ NP! & What a lovely baby you have! \\
8 & ADJ NP! & Nice game! \\
9 & Isn't NP ADJ! & Isn't your child gorgeous! \\
\end{tabular}

Source: Manes \& Wolfson, 1981, p. 20, with some modification.

The first three patterns are considered the main syntactic formulae, with the rest as being the subcategories.

The formulaic nature of compliments in English, both syntactically and semantically, has been confirmed by other researchers including Holmes (1988), Knapp, Hopper, and Bell (1984), and Wolfson (1983). In fact, Manes and Wolfson's (1981) data showed that $85 \%$ of compliments fell into the first three formulae. Holmes (1988), who replicated Manes and Wolfson's study in New Zealand, also discovered that $78 \%$ of the compliments in her study contained one of the three main formulae that were found in the American English data. In a follow up study, Wolfson (1983) found that in two-thirds of all adjectival compliments in her study only five adjectives were used namely nice (22.9\%), good (19.6\%), pretty (9.7\%), beautiful $(9.2 \%)$, and great $(6.2 \%)$.

Similar to Wolfson and Maines' study, Creese (1991) analyzed naturally-occurring compliments in England and the USA. The population of her study consisted of teachers from University of Pennsylvania and a school in London. In this cross-cultural study, Creese investigated compliment topics, syntactic patterns, compliment responses, and lexical predictability. The results of her study revealed some differences between British and American participants, i.e., the British complimented more, and the preferences in the use of syntactic categories differed in the two groups. As she explains, two major differences emerged. "One was that more than 314 of my data fell into just two syntactic formulas and the other was that, of these, the most frequent was category 2 "I (really) like/love NP" rather than category 1 "NP is/looks (Int.) ADJ." (Creese 1991, p.17). 
With regard to the role played by gender in complimenting speech act, two widely cited large-scale studies have been conducted, one by Herbert (1990) in America, and the other by Holmes (1988) in New Zealand. Apart from some differences in the frequency of the patterns used by men and women, the two studies yielded similar results with regard to formulas used by both genders. The general conclusion was that women exchange compliments more than men do. Women were also found to make more frequent use of the personal pronoun ' $\mathrm{I}$ ' in paying compliments. That is, they use the syntactic formula I like/love NP (e.g. I love your garden!) far more than men do. This finding was consistent with the results of Duan and Guo's (2009) study in China.

Additionally, Holmes (1988) found that women use the syntactic pattern What (a) (ADJ) NP! (e.g., What a lovely baby!) more frequently than men, while men preferred the short pattern (INT) ADJ (NP) (e.g. Good job!). With regard to the relation between the topic of compliments and gender, Holmes (1988) states that the frequency of compliments given and received by women on appearance is higher than those used by men. This finding was supported by further studies (Herbert 1990; Holmes 1995), which implies that women are more active in complimenting behaviour, particularly with regard to appearance.

According to Coates (1993), there is the potential for miscommunication between members of the two sexes. She maintains that gender-based research studies on complimenting speech act play a significant role in helping male and female members of a community to become familiar with each other's communication styles thereby reducing the likelihood of miscommunication. In fact, this call adds to the justification of the present study which focuses on the role of gender in compliment speech act in Turkish.

A number of studies have compared English compliment and compliment responses with other languages. In an interesting study, Lorenzo-Dus (2001) investigated compliments and compliment responses by British English and Spanish speakers. The participants were university students studying in Cardiff (UK) and Valencia (Spain). The results of Lorenzo-Dus' study showed that in order to avoid self-praise, both groups used compliments on targets such as talent and intelligence. An interesting finding of this study was the use of humor for returning a compliment. However, a difference between Spanish speakers and British speakers was that 
Spanish speakers constantly asked interlocutors to repeat the compliment. Monjezi (2014) also conducted a research on the effect of gender and proficiency level of Iranian EFL learners on the selection of topics of compliment and compliment response strategies. She found that both gender and proficiency level had an effect on compliment topics and responses, with gender having a greater role.

In another study, Yu (2005) compared American and Chinese compliments with regard to direct versus indirect strategies in giving compliments. The results of this study indicated that Americans used more direct strategies than Chinese participants, however the difference was not significant. In a similar study, Farenkia (2013) investigated compliment strategies by Canadian and Cameroonian university students. The study revealed that Canadian participants used direct strategies more than Cameroonian students.

With regard to the nature of compliments, Nelson, ElBakary, and AlBatal (1993) investigated Egyptian and American complimenting behavior, using questionnaires and interviews. The findings of their study revealed that "both Egyptian and American compliments tend to be adjectival; both frequently compliment personal appearance; Egyptian compliments tend to be longer than American compliments and contain more comparatives, references to marriage and metaphors" (p. 293). They also found that Americans tended to use more compliments than Egyptians. Another difference was with regard to topics of compliments: while Americans tended to compliment on skills and performance Egyptians complimented on personality traits more often; however, both groups were in favour of direct versus indirect compliment strategy.

Some studies have also been conducted on Turkish compliments. Ruhi (2006), for example, carried out a study on Turkish compliments with reference to the theory of politeness and conversational maxims. Ruhi (2006) stated that "people will show individual variation both in the principles that guide their (non-)linguistic behaviour and in their style of relational work but that there are conventions shared in communities of practice. For example, some individuals may have a tendency to deflect credit attributions in compliments, ... while others may prefer to accept the credit to a greater extent" (p. 96). Şakargil and Çubukçu (2012), on the other hand, conducted a study on topics and formulae of Turkish and English compliments. They classified topics into four categories: possession, appearance, performance, attribute and skill. They found that Turkish compliment formulas were more descriptive than the English ones. Another 
difference between English and Turkish compliments was that Americans used a wider range of compliments than Turkish speakers.

Regarding sample size, Holmes (1986) concludes that "patterns of complimenting behaviour in particular contexts or social groups can be investigated using smaller samples" (p.505). This seems to be particularly true with qualitative research, similar to the data of the present study.

\section{TV DRAMAS}

TV dramas or soap operas have been defined as "dramatic serial programs that are concerned with domestic crisis, often featuring little action but much sentiment" (Lambert \& Allen, 1985, cited in Lambertz \& Hebrok, 2011, p. 40). Lambertz and Hebrok (2011) state that "soap operas deal with thoughts and practical experiences of everyday life" ( $p$. 40). According to Soukup (2016), "soap operas have held a place of interest both in popular broadcasting and in communication research for over 70 years" (p. 1).

On the significance of TV dramas, Ahmed (2012) asserts that "the purpose of television is to inform, educate and entertain its viewers" and it has "a profound and persuasive impact on its viewers, particularly women" (p.10). The reason behind this is perhaps the fact that women, particularly housewives, have more time to watch TV programs in particular soap operas as the most popular television genre. The first author's observation shows that women in Iran, even in villages and remote areas, follow different TV dramas, in particular Turkish soap operas, through satellite viewing with great interest, while men are more interested in discussing socio-political and economic issues. The reason for the popularity of soap operas amongst women, according to Ahmed (2012), lies in the fact that they portray "problems and issues pertaining to women" (p.1) and in particular changes in the life style of women represented by characters in the dramas. This is in line with Gannon's (2009) assertion that soap operas, which have a large audience have an impact on society. 
Informal observation of the first author shows that satellite TV dramas have influenced the life style of women in Iran, especially with regard to fashion and dress. However, such observations need to be supported by empirical research. Some studies show that that soap operas to a large extent reflect real life situations as well as cultural changes in the life style of people, and in particular gender roles (Ahmed, 2012; Brunsdon, 2000; Doherty, 2008). For example, the British soap opera East Enders, which has been an on-going television sitcom for many years, highlights how women are portrayed in the British society.

Gannon (2009) also mentions the Turkish soap opera Noor, which reflects real life situations and cultural values. This soap opera is very popular in the Arab world, and in particular it has had a significant impact on Saudi women with regard to their perception of men. Ahmed (2012) also mentions that the developing countries have been influenced by soap operas in which issues such as divorce and marital problems have been addressed. He adds that "soap opera's concern with the everyday lives of everyday people and their problems, big and small, appears to be one of the main reasons why this genre is so popular" (Ahmad, 2012, p.2). Cevik (2014) studied soap operas from a different perspective. She examined the role of Turkish TV dramas "as a cultural diplomacy tool within the context of identity and the social implications that are prompted by these media exports" (p. 78). In other words, she claims that Turkish soap operas, which are particularly very popular in Middle-Eastern countries, have become a non-governmental tool for representing Turkish culture to the outside world.

From a pedagogical perspective, Rose (2001) carried out a research on American films which were used to measure the validity of using films for teaching compliments. The results of this study revealed that the language used in films represents the illocution of language, i.e., Pragma-Linguistic features. Negargar (2015) also conducted a descriptive study comparing the greeting speech act in a Persian soap opera hamsayeha 'neighbors' and an English soap called 'Desperate Housewives' in order to identify probable differences between the use of greeting in these two soap operas in terms of the level of formality, structure, and frequency. Similarly, Behnam and Amizadeh (2011) did a comparative study of English and Persian TV interviews with regard to the use of compliments and compliment responses. They found both similarities and differences between the complimenting behavior of English and Persian speakers on TV. 
Since studies on Turkish compliments, in general, and in films and soap operas, in particular, are scarce, the current study aims to fill this research gap and investigate the characteristics and use of complimenting behavior in a popular Turkish TV drama, with emphasis on the role of gender. The present study seeks to address the following issues:

1. Common topics and functions of Turkish compliments;

2. Main characteristics of Turkish compliments;

3. The role of gender in complimenting speech act in Turkish;

4. Similarities and differences between Turkish and English compliments.

\section{METHOD}

\section{Materials and Procedure}

The material for this study is derived from a popular Turkish TV drama called Sahra. To provide readers with the background of this Turkish soap opera some information about the drama and its main characters seems necessary.

As a typical Turkish soap opera, Sahra is also shown in neighboring countries like Iran, Jordan, and Iraq. It is dubbed into local languages or shown with subtitles. Sahra was filmed in two countries: Turkey (Istanbul) and Morocco. The drama's main theme, as summarized below, is love, betrayal and revenge.

Sahra is the daughter of a wealthy and distinguished businessman, Mr. Fahri, who adores her daughter and considers her as his most precious asset in life. Sahra lost her mother when she was young. She studied abroad and when she returned home (Turkey), she was appointed as the head of her father's company. Then, she married a middle-class man, Sinan, who settled into the rich life. Sinan has a daughter (Lara) from his former wife. Lara hates Sahra because she thinks Sahra is the cause of her parents' divorce. Mr. Fahri made his son-in-law, Sinan, the most authoritative person in his company after his daughter. Shortly after, Sahra and Sinan had a daughter, who brought further happiness to their life.

Sahra has a step-sister, Nil, who was jailed for killing her husband. When she was released prison, she realized that she had lost everything in favour of Sahra, who had control of her father's company. Therefore, she wanted to take revenge and obtain 
everything Sahra had. Hence, the return of Nil was a turning point in Sahra and Sinan's life. Another major character is Mithat who wants to take revenge on Nil for the death of his half-brother. Later he joined Sahra to help her with her revenge as well as his own, but in the process, he fell in love with Sahra.

One day, after receiving an anonymous phone call, Sahra went home and found her step-sister, Nil, in bed with her husband; consequently, she immediately decided to get divorced. Thus, she left everything behind and went to Morocco, where Sinan followed her to apologize. Nil used her friend Melek (whom she had made friends with in jail) to kill Sahra in Morocco. Melek planned to kill Sahra in a tragic car accident. Everyone thought that Sahra had died; therefore, Nil functioned as the step-mother to Lara and Ipek (Sinan and Sahra's children). However, Sahra miraculously escaped death and upon recovering from serious injuries she returned to Turkey under the false name Salma to seek revenge against her husband and her step-sister. This was the start of a major drama.

Thirty-two episodes of this soap opera were selected at random and watched a few times in order to identify compliments given by the characters in the drama. Then, the data were analyzed qualitatively, focusing on characteristics of Turkish compliments and the role played by gender in the complimenting speech act. Altogether 48 compliments were given by the characters in the TV drama. For each category of compliments only a few examples from the data are given in order to save space. In the following excerpts, first the original Turkish sentences are given, followed by literal translation, and then idiomatic English translation. In the literal translation, morphemes are separated by dashes (-). Also the following abbreviations are used to save space:

Past $\mathrm{T}=$ Past Tense

$\mathrm{PCT}=$ Present Continuous Tense

$\mathrm{PT}=$ Present Tense

$\mathrm{QM}=$ Question Marker

\section{RESULTS \& DISCUSSIONS}

\section{Topics of Turkish Compliments}

Appearance: The most frequent topic that emerged from the analysis of the data was compliments on the addressee's appearance, as the following examples illustrate.

Sahra's au pair complimenting her on her wedding dress: 
sen bugüne kadar gördüğüm en güzel gelinsin, seni bir kuğu gibisin you today until see-I most beautiful bride-you, you a swan like-PT-you

You're the most beautiful bride I have ever seen, you are like a swan.

It should be noted that in Turkish culture swan signifies beauty; therefore, comparing a woman to a swan is a compliment in Turkish.

Her aunt also gives the following compliment:

ah Sahra, tıpkı bir melek gibisin.

ah Sahra, just as one angel like-PT-you

Ah Sahra, you look just like an angel.

(In Turkish culture female complimentees are sometimes compared with heavenly creatures in order to accentuate the compliment).

In answer to Sahra's question (How are you?), Sinan says:

sana bakarken kötü olmak mümkün mü?

you-to look-while bad be-to possible-QM?

Is it possible to be bad while looking at you?

Commenting on a gift he has received from Sahra, Mithat says:

tıpkı senin gibi, zarif, şık ve göz kamaştırıcı.

just as you like, elegant, stylish and eye daze-PT-it.

It looks like you, elegant, stylish, and dazzling.

Yemin puts a shawl over Nil's shoulders while looking at her dress and says:

aslında sen ne giysen sana çok yakışıyor.

actually you what wear you-to very befit-PCT.

Actually whatever you wear looks good on you.

hatta benim pijamalarım bile sana yakışıyor.

even mine pyjamas-my even you-to befit-PCT-it.

Even you look good in my pyjamas. 
It is worth mentioning that this compliment is culture-specific as it is highly unlikely for such a compliment to be given to a woman in the Western culture. In fact, it may be considered an insult by the female complimentee.

Ability/Skill or Performance: The second most frequent topic of compliment in the current soap opera was the addressee's ability/skill and performance, as shown in the following examples.

Pelin's boss, Sahra's father, gives the following compliment on her ability and performance: ah, Pelin geldi. benim çalışkan genel müdür yardımcım. ah, Pelin came. my hard-working general principal assistant-mine.

Ah Pelin has come. She is my hard-working general secretary.

Mithat commenting on Salma's Turkish:

Türkçe’yi bir İranlıya gore şaşırtıcı derecede iyi konuşuyorsun.

Turkish-the an Iranian-to by surprising level good speak-PT-you.

You speak Turkish surprisingly well for an Iranian.

Sinan compliments on Mithat's performance:

bu beni ikinci şok edişin. raporlara baktım ve kusursuz görünüyorlar.

this me-to second shock the way-you. reports look-PastT-I and perfect look-they This is the second time you've shocked me. I looked at the reports and they look perfect.

Salma commenting on Mithat's ability:

Mithat çok yeteneklidir.

Mithat very talent/capable-is.

Mithat is very capable/talented.

An interesting observation here is that comparison of these compliments with those on appearance shows that they are shorter than the latter. This may be due to the fact that when people compliment on appearance, especially when the complimentee is a female, they are likely to exaggerate hence longer compliments.

\section{Functions of Compliments}


Admiration: The function of both types of compliments explained above (those on appearance and ability/performance) is admiration whose purpose is to achieve certain pragmatic functions, such as gaining a favour or winning the heart of the addressee, particularly when the complimentee is a woman, as is the case in most compliments in this study. In such cases, the complimenter praises the beauty, appearance or ability/skill of the complimentee, sometimes in a flattery and exaggerated fashion, as illustrated above.

Opening/sustaining a conversation: The second function that emerged from the data was using compliments to open or sustain a conversation (Wolfson, 1983; Billmyer, 1990), as illustrated in the following compliments:

In a scenario, Melek answers the door, and Hakan gives a compliment on Melek's dress, the purpose of which was simply to open a conversation:

Melek bu elbise sana çok yakışmış.

Melek this dress you-to very befit.

This dress really looks lovely on you, Melik.

In another scenario, Sahra and Mithat are exchanging gifts at their home before New Year's Eve and at the same time they exchange compliments to keep the flow of conversation going.

Sahra: beğendin mi?

like-you-Past T-it QM?

Did you like it? (referring to the gift)

Mithat: Çok! tıpkı senin gibi; zarif, şık ve nefes kesici. a lot! just as-you like; elegant, smart and breath take.

A lot! It looks like you; elegant, smart and breath-taking.

Mithat: hayatıma girerek, hayatımı, evimi aydınlattın ve şimdi life-my-to enter, life-my, home-my brighten+Past T-you and now sabahları uyanmak için bir sebebim var. morning wake up for one reason-mine have. By coming into my life, you've brightened my life, my home, and now I 
have a reason to wake up in the morning.

\section{Frequency of the Topics of Compliments}

Although this study is qualitative by nature, it was decided to obtain the frequency of topics of compliments in order to compare them with the results of other related studies. Table 2 displays the frequency of topics of compliments.

Table 2. Frequency of occurrence of topics of compliments

\begin{tabular}{lcc}
\hline Topic & No. & $\%$ \\
\hline Appearance & 35 & 73 \\
Ability/Skill\& Performance & 13 & 27 \\
\hline Total & & \\
\hline
\end{tabular}

As Table 2 illustrates, appearance enjoys the highest frequency (73\%) in the complimenting behaviour of Turkish characters in the soap opera for the reasons that will be explained in the following section. Appearance in this study includes beauty, clothes, body parts (e.g., eyes), and comparison of the complimentee with supernatural beings such as angels. The next most frequent category is ability/skills and performance with $27 \%$ of occurrence.

Next, the percentages of the interaction between gender and topics of compliments were obtained, as presented in Table 3.

Table 3. Interaction between gender and topics of compliment

\begin{tabular}{lcccc}
\hline Topic & F-F & M-F & F-M & M-M \\
& & & & \\
\hline Appearance & 20 & 68.60 & 11.40 & 0 \\
Ability/Performance & 7.70 & 15.40 & 53.83 & 23.07
\end{tabular}

In order to compare these results with those of similar studies on the interaction between gender and compliments, a similar table provided by Sun (2013, p. 216), summarizing the 
findings of gender-based research (e.g., Herbert, 1990; and Holmes, 1988, 1995), in particular Holmes' (1988) study, is presented in Table 4.

Table 4. Interaction between gender and topics of compliments

\begin{tabular}{lllll}
\hline Topic & F-F & M-F & F-M & M-M \\
& & & & \\
\hline Appearance & $61 \%$ & $47 \%$ & $40 \%$ & $36 \%$ \\
Ability/Skill/Performance & $20 \%$ & $44 \%$ & $35 \%$ & $32 \%$ \\
& & & &
\end{tabular}

Source: Sun, 2013, p. 216

Comparison of the two tables yields interesting results. As can be seen, there are similarities and differences between the two tables. First of all, appearance is the most frequent topic of compliments for both genders in the two tables; however, the distribution of compliments between and across gender is different in the two tables. In Table 4, the majority of compliments on appearance $(61 \%)$ were given by women to women; whereas, in the present study (Table 3 ), the highest percentage $(68.60 \%)$ is attributed to compliments given by male to female characters. Similarly, in Table 4, $40 \%$ of compliments on appearance are given by women to men while this percentage is very low in the current study $(11.40 \%)$. The reason for this discrepancy lies in the fact that in Turkish culture there seems to be a tacit restriction on women's complimenting on men's appearance; whereas, in the English-speaking culture it is quite normal for women to compliment on the appearance of men. Another major difference between the two tables is that in Table 4, 36\% of compliments on appearance are exchanged between men; whereas, in the present study there was no compliment on appearance between male characters in the TV drama as it is not customary for men in Turkish culture to compliment on other men's appearance. However, women in this study did compliment on other women's appearance $(20 \%)$.

There are also differences with regard to the second topic namely ability and performance, with reference to gender. In Sun's table, 44 per cent of men's compliments are on women's ability and skill. In contrast, in the present research the percentage of men's compliments on 
women's ability/skill is much lower (15.40\%) than the percentage of women's compliments on men's ability/skill (53.83\%). There is also a difference between women to women compliments on ability and skill (20\% in Sun's study versus $7.70 \%$ in the present study). Similarly, the percentage of men to men compliments on ability in Sun's study was $32 \%$ while in the present research it was 23.07 .

\section{The Main Characteristics of Turkish Compliments}

The qualitative analysis of the data led to the emergence of two major characteristics of Turkish compliments namely elaboration and exaggeration.

Elaboration: With regard to the first characteristics, it appears that in Turkish culture compliments are normally long and elaborate. That is, the speaker first sets the scene and paves the ground then s/he pays a compliment. A couple of examples from the data illustrate this elaborate and complex style of complimenting in Turkish, as follows.

Complimenting on the beauty of a female character, a male character says: İnsan hergün bir prensesle karşılaşmıyor, değil mi? Özellikle kel, şapkalı human everyday one princess-with meet-not-he/she, right-QM? especially bald, hat-with birini beklerken (bir erkek olan iş ortağını kastederek), ve aniden güzel someone wait-while (a man become work partner refer), and suddenly beautiful bir kadın size doğru yürüyor. one woman you-to ahead walk-PCT-she.

A person doesn't get to meet a princess every day, right? Especially when you're expecting a bald, hooded man (referring to a male business partner), and suddenly a pretty lady like you walks in.

While dancing with Salma, Mithat says:

aslında güzel kadınlarla konuşmakta zorlanmam aksine zevk alırım actually beautiful ladies-with speak-to problem-no-I contrary enjoy take-I, ama siz... aklımı öylesine karıştırıyorsunuz ki söyleyecek söz but you...mind-mine such confuse-you that say-will word bulamıyorum. bir insanın içine işleyen güzelliğin sırrı ne? 
find-can't-I. one human's into activate beauty-the secret what? Actually, I normally don't have any problem speaking to ladies. On the contrary, I enjoy doing so, but you are perplexing my mind; I can't find the right words to express myself. What is the secret behind the beauty that takes over a person?

In this example, the complimenter does not give a compliment directly without an introduction. Instead, he first provides some background information by saying "Actually, I normally don't have any problem speaking to ladies". Then, he explains his difficulty in finding the right words to speak to this particular woman being awed by her beauty, in order to accentuate the compliment. The pragmatic function of such an elaborative compliment is to win the heart of the woman he is speaking to by using flattery compliments. This seems to be just the opposite of the common trend in English-speaking communities.

That is, speakers of English normally use direct strategies in giving compliments, employing a small number of syntactic patterns. For example, Manes \& Wolfson (1981) found that the naturally-occurring compliments in their study are extremely formulaic speech acts since a very small set of syntactic patterns and lexical items constitute the great majority of compliments in their large-scale study consisting of 686 compliments. This finding is in line with Holmes's (1986) study in New Zealand consisting of 517 compliments. Jucker, Schneider, Taavitsainen, and Breustedt (2008) also state that "compliments are highly routinized and formulaic" (p. 274). Similarly, Yu (2005) reports that the American participants in his study used direct strategies of giving compliments in the majority of cases (91.1\%). The same trend was found to be the case with regard to Canadian students, who share the same language and similar culture with Americans. That is, in a study, Farenkia (2013) investigated compliment strategies by Canadian and Cameroonian university students. It was revealed that Canadian participants used more direct compliment strategies than their Cameroonian counterparts. On the other hand, the frequent use of indirect compliments by Cameroonian students in the same study is in line with the findings of the present study, perhaps due to cultural similarities.

Owing to the elaborate and descriptive nature of Turkish compliments, they tend to be lengthier than the English ones. As mentioned above, Manes and Wolfson (1981) found that Americans follow a limited number of formulaic patters and lexical items, such as ADJ NP! 
(Nice job!), NP is/looks ADJ'(It's wonderful)', or You (really)V(NP) ADV (You treated him nicely). As can be seen, such patterns are rather brief and rigid. In contrast, as illustrated above, Turkish compliments mostly consist of more than one clause or sentence. Similar to the findings of the present study, Şakargil and Çubukçu (2012) found compliment formulas in Turkish to be descriptive. Nelson, ElBakary, and AlBatal (1993) also discovered that "Egyptian compliments tend to be longer than American compliments and contain more comparatives, references to marriage and metaphors" (p. 293). The use of indirect and elaborate compliments in the present study is consistent with Negargar's (2015) finding that "Iranians tend to use expressions that are less direct, more polite, potentially less clear, longer, and with more complex structures" (pp. 56-57). Based on the results of these studies, which confirm the findings of the present research, it can be concluded that elaborate and descriptive compliment speech act is a feature of the Middle-Eastern culture.

Exaggeration: Another characteristic of Turkish compliments is exaggeration, as evident in the following compliments.

In answer to Feyza's offer for a drink, Nihat says:

elinizden zehir olsa içerim.

hand-your-from poison even drink-PT-I

I would drink even poison that comes from your hand.

Mithat compares Sahra to an angel and says:

kanatlarını nereye sakladı̆̆ını bir bulabilsem

wings-the where hide-you one find-could

If I could find out where you hide your wings.

Yemin compares Nil to a flower:

bu havuzdaki tek eksik çiçek sensin.

this pool-in only missing flower you+PT

You're the only flower that is not in the pool (referring to a swimming pool full of flowers and surrounded by lit candles on the sides, prepared by Yemin to impress and please Nil).

It seems that the female complimentees are aware of the exaggerated compliments given to them as the following exchange illustrates. 
Mithat: bu güzelliğe inanamıyorum.

this beauty believe-can't-I

I can't believe in this beauty

Sahra: abartiyorsun!

exaggerate-PCT-you!

You're exaggerating!

Contrary to this finding, widely-cited studies on English speakers' complimenting behaviour (e.g., Herbert, 1990; Holmes, 1986, 1988, 1995; Jucker et al., 2008; Knapp, Hopper, \& Bell, 1984; Maines, \& Wolfson, 1981; Wolfson, 1983; Yu, 2005) reveal that native speakers tend to avoid using elaborate and exaggerated compliments by giving direct and short compliments, such as Well-done!, Nice game!, and A brilliant presentation!.

\section{The Role of Gender}

The analysis of the data shows that in the majority of cases male characters in the Turkish soap opera gave compliments to females, as illustrated in Table 3. Altogether, female characters received $68.60 \%$ compliments on appearance from men and gave only $11.40 \%$ compliments to them. This is in stark contrast with the findings of some other studies (Herbert, 1990; Holmes, 1988, 1995; Duan \& Guo, 2009; Sun, 2013) indicating that women are more active in complimenting behaviour than men. The reason for the low percentage of females' compliments on men in the present study seems to be due to cultural restrictions, as explained above.

The finding of this study is also in contradiction with Matsuura's (2004) study in which "American females indicated a significantly greater likelihood to give compliments than American males" (p. 164) while in the present study the reverse was true.

With regard to the interaction between gender and topics of compliments, the findings of Holmes's (1988) study, which was supported by further studies (Herbert, 1990; Holmes, 1995), revealed that women exchange compliments on appearance of the addressee more than men do. On the contrary, women in the present study were mainly the recipient of compliments on appearance and they rarely gave compliments on men's appearance for the cultural reasons explained above. 
A good proportion of compliments given by men to women (44\%) in Holmes' (1988) study were on ability or skill; whereas, in the present study such compliments had low frequency compared to compliments on appearance (15.40\%), compared to $68.60 \%$ on appearance. Another interesting finding with reference to gender is that male to male compliments had very low frequency in the data, as displayed in Table $3(23.07 \%$ on ability/skill and none on appearance).

Yet another finding of this study with regard to gender differences is that female characters' compliments were much shorter than those given by their male counterparts, as the data presented above shows, a few of which are repeated bellow for the sake of illustration.

Mithat çok yeteneklidir.

Mithat-very-talent+be-PT

Mithat is very talented.

harika görünüyorsun.

amazing - look+PCT +you.

You look amazing.

Çok düşüncelisin.

very thoughtfull-PT-you.

You're so thoughtful.

With regard to the topics of compliments, the results of the present study indicated that appearance of the complimentee was the most frequent topic (73\%). This finding supports Göregenli's (1997) assertion that in Turkish culture people are concerned with the way they look. In the same vein, Nelson et al. (1993) found that both Egyptians and Americans frequently compliment on personal appearance. The finding is also consistent with the result of Knapp et al.'s (1984) study confirming that in their American data, compliments on the addressee's appearance and performance (i.e., abilities and skills) enjoyed the highest frequency. Holmes (1986) also found that the vast majority of compliments in her study (81.3\%) were on appearance, ability/performance, with "appearance 50.7\%, and ability/performance $30.6 \%$ " (p. 496).

Ability/skill and performance enjoyed the second highest percentage (27\%) in the present study. However, the results of the current research are in stark contrast with those of Şakargil and Çubukçu (2012) with regard to topics of compliments, despite the fact that both studies deal with Turkish compliments. In their study, the most frequent topic was possession, with 
appearance being in the third position. The reason for this discrepancy seems to be the fact that Şakargil and Çubukçu considered clothes as possession, while in present study they are included in appearance since people buy nice clothes to look good, not just to possess them. As mentioned before, in Turkish culture people are concerned with the way they dress and look (Göregenli, 1997). Another factor that has affected the differences in the results of the two studies is that in Şakargil and Çubukçu's (2012) research, unlike the present study, features such as haircuts were not treated under the category of appearance, while we believe they should be. In fact, this is consistent with the views of other researchers in the field regarding items of appearance (see, e.g., Cordella, Large, \& Pardo, 1995; Herbert, 1989; Manes \& Wolfson, 1981; Matsuura, 2004; Sun, 2002; Wolfson, 1983).

\section{CONCLUSION}

Compliments seem to play a vital role in face-to-face interactions in Turkish culture, and presumably in any other culture as they are the most obvious face-saving speech act. Compliments appeal to people's positive face needs since it is part of the human nature to be admired by others. For this reason, people in most communities, especially women, do care about their appearance. Thus, it is not surprising that, as the results showed, appearance was the most popular topic of compliments by Turkish speakers in the present study. It seems that in Turkish culture admiration is used to create a harmony in communication with others. The fact that many studies, as mentioned before, have shown that appearance is a popular topic of compliment point to the universal need of people to be admired.

Another conclusion that can be drawn from the findings of the present study is that elaboration and exaggeration are two features of the Turkish culture in so far as complimenting behaviour of people is concerned. The implication of this finding for non-Turkish citizens, such as tourists, is that familiarity with such features may prove helpful in preventing culture misunderstanding and enhancing intercultural communication.

\section{LIMITATIONS}

Considering the small sample size (only one soap opera), it is not realistic to consider the results of the present study as definitive, rather they can only be indicative of certain trends in 
complimenting behavior in the Turkish culture. To achieve more validity and wider generalizability, more soap operas need to be examined and analyzed in future research in the light of compliment speech act.

Another limitation of the study is that it was restricted to a Turkish soap opera. Future studies may consider comparing Turkish soap operas with those in other languages, in particular English.

\section{REFERENCES}

Ahmed, A. (2012). Women and soap-operas: Popularity, portrayal and perception. International Journal of Scientific and Research Publications, 2(6), 1- 6.

Al-Mansoob, Najeeb Taher, K. S. Patil, K. S., \& Alrefaee, Yasser Mohammed (2019). A Crosscultural study of the speech act of compliments in American English and Yemeni Arabic. LANGKAWI Journal, 5(1), 1-12.

Baek, G.(1998). A cross-cultural study of compliments and compliment responses in English and Korean. Unpublished doctoral dissertation. Seoul National University, Seoul.

Behnam, B., \& Amizadeh, Niloufar (2011). A comparative study of the compliments and compliment responses between English and Persian TV interviews. 3L: The Southeast Asian Journal of English Language Studies, 17(1), 65-78.

Billmyer, K. (1990). I really like your lifestile: Learners learning how to compliment. Penn Working Papers in Educational Linguistics, 6(2), 31-48.

Boroujeni, A. J., Domakani, M. R., \& Sheykhi, S. (2016). Comparative cross-cultural analysis of compliments in English and Persian series. Journal of Applied Linguistics and Language Research, 9(2), 177-187.

Brown, P., \& Levinson, S.D. (1987). Politeness: Some universals in language usage. Cambridge: Cambridge University Press.

Brunsdon, C. (2000). The feminist, the housewife, and the soap opera. New York: Oxford.

Çevik, B. Senem (2014). Turkish soap opera diplomacy: A Western projection by a Muslim source. Exchange: The Journal of Public Diplomacy, Vol. 5, Iss. 1, Art. 6

Coates, J. (1993). Women, men, and language: A sociolinguistic account of gender differences in language. London: Longman.

Creese, A. (1991). Speech act variation in British and American English. Penn Working Papers in Educational Linguistics, 7(2), 37-58. 
Cordella, M, Large, H., \& Pardo, V. (1995). Complimenting behavior in Australian English and Spanish speech. Multilingua, 14(3), 235-252.

Doherty, G. (2008). On quality in education. Quality assurance in Education, 16(3), 255-265.

Duan, Cheng-gang, \& Guo, Kan-jun (2009). Sex-based differences in Chinese written compliment behavior. Journal of University of Science and Technology, Beijing, Social Sciences Edition, 25(3), 109-115.

Eslami, Z. R., Jabbari, N., \& Kuo, Li-Jen (2015). Compliment response behaviour on Facebook: A study with Iranian Facebook users. International Review of Pragmatics 7, 244-277

Farenkia, B.M (2013). Canadian and Cameroonian English-speaking university students' compliment strategies. International Journal of Linguistics, 5(3), 69-98.

Furko, B. P., \& Dudas, E. (2012). Gender differences in complimenting strategies with special reference to the compliment response patterns of Hungarian undergraduate students. Argumentum, 8, 136-157.

Gannon, C. (2009). Feminism \& soap opera. Social \& Political Review, 19, 87-97. Dublin: Trinity College.

Göregenli, M. (1997). Individualistic-collectivistic tendencies in a Turkish sample. Journal of Cross-Cultural Psychology, 28(6), 787-794.

Herbert, R. K. (1990). Sex-based differences in compliment behaviour. Language in Society, $19,201-224$.

Holmes, J. (1986). Compliments and compliment responses in New Zealand English. Anthropological Linguistics, 28(4) 485-508.

Holmes, J. (1988). Paying compliments: A sex-preferential politeness strategy. Journal of Pragmatics, 12, 445-465.

Holmes, J. (1995). Women, men and politeness. London: Longman.

Jucker A. H. et al. (2008). Fishing for compliments. In Andreas. H. Jucker \& Irma Taavitsainen (Eds.), Speech acts in the history of English (pp. 273-294). Amsterdam: John Benjamins.

Keshavarz, M. H. (2015). Contrastive Analysis, Error Analysis, and Interlanguage (Revised Edition). Tehran: Rahnama Press.

Knapp, M., Hopper, R., \& Robert A. Bell (1984). Compliments: A descriptive taxonomy. Journal of Communication, 34, $12-31$. 
Lambertz, K, \& Hebrok, M. (2011). Women's Language in Soap Operas. Griffith Working Papers in Pragmatics and Intercultural Communication 4, 1(2), 39-54.

Lorenzo-Dus, N. (2001). Compliment responses among British and Spanish university students: A contrastive study. Journal of Pragmatics, 33(1), 107-127.

Manes, J. \& Wolfson, N. (1981). The compliment formula. In F. Coulmas (Ed.), Conversational routine: Explorations in standardized communication situations and prepatterned speech (pp. 116-132).The Hague, Netherlands: Mouton Publishers.

Manes, J. (1983). Compliments: A mirror of cultural values. In N. Wolfson and E. Judd (Eds.), Sociolinguistics and language acquisition (82-95). Rowley, MA: Newbury House.

Matsuura, H. (2004). Compliment-giving behavior in American English and Japanese. JALT Journal, 26(2),147-170.

Monjezi, M. (2014). The effects of proficiency and gender on the compliments and compliment responses made by Iranian EFL learners. International Journal of Language Learning and Applied Linguistics World 5(1), 625-638.

Morales, R.C (2012). Compliment responses across gender in Philippine context. $3 L$ : The Southeast Asian Journal of English Language Studies, 18(1), 47-60.

Negargar, (2015). A contrastive study of speech act of greeting in two Persian and English soap operas with regard to the level of formality, structure and frequency. International Journal of Research in Humanities, Arts and Literature, 3(6), 47-60.

Nelson, G., L, ElBakary, Waguida, \& Al-Batal, Mahmoud (1993). Egyptian and American compliments: A cross-cultural study. International Journal of Intercultural Relations 17(3), 293-313.

Rapping, E. (2002). Daytime utopias: If you lived in pine valley, you'd be home. In. Henry Jenkins, Tara McPherson, \& Jane Shattuc (Eds.), Hop on Pop: The politics and pleasure of popular culture (pp.47- 65). Durham: Duke University Press.

Rose, K. (2001). Compliments and compliment responses in film: Implications for pragmatics research and language teaching. International Review of Applied Linguistics, 39, 309-326.

Ruhi, Ş. (2006). Politeness in compliment responses: A perspective from naturally occurring exchanges in Turkish. Pragmatics, 16(1), 43-101.

Saifi, M.A, \& Sultani, Ahmad, S.S (2017). Compliment and compliment responses: A comparative study between Dari and English native Speakers. International Journal of Scientific and Research Publications, 7(11), 104-109. 
Şakırgil, C. \& Çubukçu, H. (2012). Formulas and topics in Turkish and English compliments. Procedia-Social and Behavioral Sciences, ELSEVIER 70, 1126- 1135.

Salgado, E.F \& Witten, M. T. (2019). A comparative study of Mexican and Irish compliment responses. Colomb. Appl. Linguist. J., 21(1), pp. 125-138. http://dx.doi.org/10.14483/22487085.14670

Sawadogo, M. (2018). The concept of complimenting in light of the Moore language in Burkina Faso. Pragmatics, 28(1), 139-156.

doi 10.1075/prag.00005.saw issn 1018-2101/e-issn 2406-4238

Shokouhi, S \& Rezaei,A. (2015). The importance of teaching pragmatics in the classroom (Focus on complimenting). Journal for the Study of English Linguistics 3(1), 101-107. doi: 10.5296/jsel.v3i1.7890

Soukup, P.A. (2016). Studying soap operas. Communication Research Trends, 35(3), $3-55$.

Sun, N. (2013). Gender-based differences in complimenting behaviour: A critical literature review. The ANU Undergraduate Research Journal, 5, 213-222.

Sun, Z. (2002). A study of gender differences in compliments and compliment responses in Chinese context. Unpublished MA dissertation, School of Foreign Studies, Anhui University.

Wolfson, N. (1983). An empirically-based analysis of complimenting in American English. In N. Wolfson \& E. Judd (Eds.), Sociolinguistics and Language Acquisition (pp. 82-95). Rowley, MA: Newbury House.

$\mathrm{Yu}$, M. C (2005). Sociolinguistic competence in the complimenting act of native Chinese and American English speakers: A mirror of cultural value. Language and Speech, 48(1), 91119. 
Mohammad Hossein Keshavarz, Yasemin Çetereisi, Gulay Asit 